Mini-Review

Journal of Cellular Physiology

Review article

\title{
The non-conventional effects of glucocorticoids in cancer $^{\dagger}$
}

Simra Azher ${ }^{1}$, Omid Azami ${ }^{1}$, Caterina Amato ${ }^{1}$, Michael McCullough ${ }^{1,2}$, Antonio Celentano ${ }^{1,3}$,

Nicola Cirillo ${ }^{1,2}$

${ }^{1}$ Melbourne Dental School, University of Melbourne, 720 Swanson Street, Carlton, Victoria, Australia

${ }^{2}$ Oral Health Cooperative Research Centre (CRC), University of Melbourne, 720 Swanson Street, Carlton, Victoria, Australia

${ }^{3}$ Department of Neurosciences, Reproductive and Odontostomatological Sciences, University

Federico II of Naples, Via Pansini 5, Naples, Italy

\begin{abstract}
${ }^{\dagger}$ This article has been accepted for publication and undergone full peer review but has not been through the copyediting, typesetting, pagination and proofreading process, which may lead to differences between this version and the Version of Record. Please cite this article as doi: [10.1002/jcp.25408]
\end{abstract}

Additional Supporting Information may be found in the online version of this article.

Received 25 April 2016; Revised ; Accepted 25 April 2016 Journal of Cellular Physiology (C) 2014 Wiley Periodicals, Inc. DOI: 10.1002/jcp.25408 


\section{Address for correspondence N Cirillo}

Melbourne Dental School and Oral Health CRC

University of Melbourne, 720 Swanston Street

3053 Carlton, VIC, Australia

Tel/fax: +61393411473

E-mail: Nicola.cirillo@unimelb.edu.au 


\section{Abstract}

Synthetic corticosteroids are widely used for the treatment of a variety of diseases, including premalignant and malignant conditions. In striking contrast, recent evidence suggests that corticosteroids can bear tumour-promoting effects in solid tumours of epithelial origin. We have recently shown that epithelial tissues, including the mucosa of the oral cavity and the skin, are able to modulate the local concentration of active corticosteroids and to produce steroids de novo. This has important clinical and physiopathological implications, because tissue-specific regulation of glucocorticoids plays a key role in the overall effect of these molecules. In the present review of the current English literature, performed using MEDLINE / PubMed / Ovid databases, we collected published evidence to demonstrate that corticosteroids induce effects that are more complex and controversial than previously acknowledged. Published studies clearly demonstrate that this class of molecules influences pathophysiological processes that are strictly related to malignancy, providing the rationale for further investigation.

Keywords: glucocorticoids, $11 \beta$-HSD, cancer, proliferation, apoptosis, chemotherapy

\section{Introduction}

Cortisol is an endogenous glucocorticoid (GC) hormone produced by the adrenal cortex in response to adrenocorticotropic hormone (ACTH), and it is released in response to various stress stimuli. ACTH secretion from the pituitary gland is a result of hypothalamus activation. GCs have long been regarded as drugs that promote apoptosis and inhibit cell proliferation and wound healing (Schlossmacher et al., 2011). However, a body of evidence has mounted over the last ten 
years that shows potentially harmful effects of GCs in cancer therapy. Data from laboratory, preclinical, and clinical studies suggest that glucocorticoids induce treatment resistance in solid tumours, including prostate, ovarian and breast cancer (Herr and Pfitzenmaier, 2006). Our data also support this view by demonstrating that cortisol significantly reduces the cytotoxic effects of chemotherapeutic agents in several cell lines from oral squamous cell carcinoma (OSCC) (Celentano et al, manuscript in preparation). GCs also form the mainstay of the therapeutic armamentarium of a number of diseases with malignant potential, such as oral lichen planus (OLP). Therefore, the potential pro-tumorigenic activity of GCs can have vast clinical implications and warrants urgent attention.

Recent research demonstrates that epithelial cells, including those lining the skin and oral mucosa, can metabolize glucocorticoids de novo from cholesterol or systemic steroid intermediates. It has been shown that there is an endogenous non-adrenal glucocorticoid system existing in human epidermal keratinocytes and they exhibit high levels of corticosteroid metabolising activity (Slominski et al., 2014). Keratinocytes express major enzymes involved in the synthesis and metabolism of cortisol, including; cytochrome P450 chain, 11b-hydroxysteroid

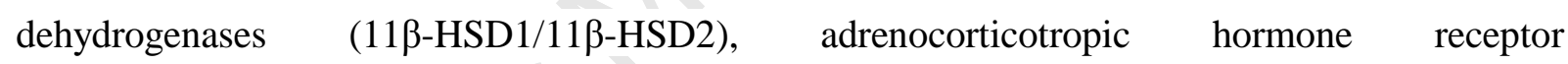
(ACTHR/MC2R) and glucocorticoid receptor (Cirillo and Prime, 2011). Alteration of both the Hypothalamus-Pituitary and Adrenal (HPA) axis and non-adrenal tumour-associated glucocorticoid system has been linked to carcinoma progression as it results in altered cortisol levels (Bernabé et al., 2012; Rasmuson et al., 2001). These data may have major implications for cancer pathophysiology and therapy, as GCs are routinely administered during cancer treatment.

This paper primarily aimed to review the current evidence supporting the traditional (conventional) and non-conventional role of GCs in normal and malignant cells. 


\section{Effects of GCs on epithelial cells - Conventional and non-conventional effects}

GCs are conventionally used to up-regulate anti-inflammatory factors and down regulate proinflammatory factors. In oncology, GCs have been widely used in association with other treatment for cancer patients because they have potent proapoptotic properties in lymphoid cells, can reduce nausea and acute toxic effects in healthy tissue (Herr and Pfitzenmaier, 2006). However, a number of secondary effects have been documented that influence a variety of functions such as cell migration, differentiation, apoptosis and proliferation.

\section{Role in cell proliferation and apoptosis}

The anti-inflammatory and pro-apoptotic effects of GCs (Feng et al., 2013; Sidler et al., 2011) are fundamental in their use as therapeutic agents. However, as showed on normal human epidermal keratinocytes, the cortisol can exerts both immunostimulatory and immunosuppressive activities depending on its concentration (Itoi et al., 2013).

GCs are able to alter signalling in key survival pathways and this can result in reversible growth arrest or cell death in certain cell types, which may be particularly important in the arrest of tumour cell proliferation (Schlossmacher et al., 2011). However, although GCs are conventionally used to treat cancer or as adjuvants in cancer treatment, it has been observed that they may in fact induce tumour growth and metastasis formation (Deguchi et al., 1998; Romero et al., 1992). The underlying mechanism in which GCs induce tumour growth has been explored and it has been proposed that the hyper-secretion of GCs decreases peripheral blood lymphocytes (PBLs); cells which play a central role in killing tumour cells (Deguchi et al., 1998). Alternatively, studies have focused on the fact that GCs are inhibitory to the immune system and thus may inhibit certain molecules which are known to be tumouricidal (Irwin 1991). 
Whilst the phenomenon of glucocorticoid-induced apoptosis in haematological cells is well established (Olnes et al., 2016), a growing body of evidence now suggests that glucocorticoids can act as anti-apoptotic agents in epithelial cells to promote cancer progression. It has been demonstrated that elevated levels of GCs during chronic restraint stress mediate an inhibitory effect on the tumour suppressing protein p53 thereby promoting tumourigenesis (Feng et al., 2012). Moreover, extra-adrenal GCs produced by intestinal epithelium have been implicated in aiding the progression of colon carcinoma cells through an immune evading mechanism (Sidler et al., 2011). The colon carcinoma cells synthesize and release bioactive immunosuppressive GCs which in turn suppress T-cell activation (Sidler et al., 2011).

Guendisch et al. analysed the role of glucocorticoids (GCs) in the survival and proliferation of tumor cells. The non-apoptotic actions of glucocorticoids on tumour cell lines, primary tumor cells and an in vivo model along with molecular signalling studies were examined. The first important finding of this study was that dexamethasone, a commonly used glucocorticoid in cancer patients, enhances tumour cell proliferation in vitro and in vivo. Dexamethasone enhanced tumour cell proliferation in 9/17 cell lines from solid tumours from all three different germ layers (Guendisch et al., 2012). It was found that these dexamethasone-induced proliferative changes were mediated by the glucocorticoid receptor. GCs lead to an activation of intracellular signalling molecules such as N3RC1, AKT and p38-MAPK which all function in various ways to mediate dexamethasone-induced tumour cell proliferation. In terms of clinical relevance, the findings from this paper suggest that the non-use of GCs might actually improve the prognosis of patients with cancer (Guendisch et al., 2012). Moreover, Dexamethasone showed to suppress antitumor immune responses and facilitate tumor progression by enhancing PD-1, a key cell-surface receptor of CD28 superfamily that can attenuate T-cell responses and 
promote T-cell tolerance, resulting in faster tumor growth and poor prognosis in the clinical setting of anti-cancer therapy (Xing et al., 2015).

A reported well-known effect of GCs is their ability to inhibit cell proliferation (Newton, 2000; Rabbitt et al., 2003; Spiegelman et al., 1997, Yuan et al., 2016). However, it has also been shown that cortisol can increase cell proliferation at certain concentrations. Cortisol concentration modulates the level of Interleukin-6 (IL-6), a cytokine that stimulates the growth of cancer cells via an autocrine mechanism (Bernabé et al., 2011). IL-6 has been associated with angiogenesis and tumour progression (Heikkilä et al., 2008, Jobe et al., 2016). In head and neck SCC it can be correlated with recurrence, lymph node recruitment, and a poor prognostic survival (Duffy et al., 2008; Nagata et al., 2003). At higher concentrations of cortisol (100 and 1000nM) there is a lower level of IL-6 mRNA expression and secretion in oral SCC. However, at cortisol concentrations that simulate physiological stress levels (10nM) there is an increase in IL-6 mRNA expression and secretion with a subsequent increase in cell proliferation (Bernabé et al., 2011).

There is also support for this increase in cell proliferation, as a result of cortisol treatment, in non-malignant situations. This has been documented in foetal cardiomyocytes and Purkinje fibres (Feng et al., 2013). Cell nuclei expressing Ki67; a marker for cell proliferation, were found in greater numbers in foetal heart tissue that were infused with cortisol. The myocyte proliferation due to exogenous GC treatment resulted in cardiac enlargement and hypertrophy leading to increased wall thickness. The proliferative effects of cortisol were blocked by the use of an antagonist to the mineralocorticoid receptor, which is a receptor of particular interest because it can be found in the epidermis of skin and interacts with the 11 $\beta$-HSD enzyme (Kenouch et al., 1994). In foetal hearts it was found that there was an increase in apoptosis in 
Purkinje fibres which was blocked through the use of a specific antagonist to the GR (Feng et al., 2013). In contrast, GR activation in cardiomyocytes has an anti-apoptotic effect, reflecting another non-conventional effect (Ren et al., 2012).

Studies on the transcriptional profiles of primary human keratinocytes revealed further evidence for the non-conventional anti-apoptotic effect. The treatment of keratinocytes with dexamethasone promoted anti-apoptotic gene expression and inhibited pro-apoptotic expression. As a result, the treated keratinocytes did not undergo UV-induced apoptosis (Stojadinovic et al., 2007). To explain the presence of both apoptotic and anti-apoptotic properties of GCs it has been suggested that they are not mutually exclusive and these effects may occur at different stages i.e. GCs inhibit early stages of differentiation and promote later stages of differentiation. (Stojadinovic et al., 2007). Therefore, GCs can have different effects depending upon cell type, developmental age and cellular environment (Feng et al., 2013).

\section{Role in wound healing and anchorage independence}

Delayed wound healing is a well-known effect of the therapeutic use of GCs. It has been shown that overexpression of the GR in transgenic mice slows down the skin wound healing process. This delay is attributed to the inhibition of keratinocyte proliferation, motility and migration. Furthermore, delayed wound healing is accompanied by a decrease in granulocyte and macrophage recruitment, as well as a reduction in ERK activity and the expression of TNF- $\alpha$, IL$\beta$, proangiogenic factor and vascular endothelial growth factor (Sanchis et al., 2012; Stojadinovic et al., 2007). However, conflicting results have suggested that in fact GCs may have some repair potential. In one particular experiment, mucociliated human bronchial epithelial cell (HBEC) cultures were created to imitate an asthmatic environment and the effects of therapeutic agents 
such as dexamethasone were studied. As expected, it was found that dexamethasone delayed immediate wound repair of HBEC by lowering the proliferative rate of cells surrounding the injured site. However, this in turn reduced proliferative stress on epithelial stem cells and transit amplifying cells in the basal compartment of the bronchial epithelium during post-wound metaplasia. Hence, the functional lifespan of these replacement cells is enhanced leading to better long term repair potential (Wadsworth et al., 2006).

GCs have long been used as agents in the treatment and management of particular diseases. The effects of commonly used GC medications to treat pemphigus vulgaris (PV) were studied to demonstrate whether their supposed therapeutic properties in regenerating PV-like lesions could be demonstrated in vitro. Using methylprednisolone (MP) and pyridostigmine bromide (PBr) this study found that MP and $\mathrm{PBr}$ significantly improved the rate of keratinocyte wound regeneration associated with PV lesions. However, it was found that these drugs could not accelerate the rate of wound healing in monolayers cultured under no conditions. This suggests that $\mathrm{MP}$ and $\mathrm{PBr}$ function to specifically offset the effects of PV serum on wounded keratinocytes (Lanza et al., 2009). Other studies have explored the effects of both endogenous and exogenous corticosteroids on human keratinocyte survival and proliferation rates.

The capacity of human keratinocytes to promote the formation of anchorage-independent multicellular aggregates (MCAs) in vitro was studied using endogenously-produced and exogenously administered hydrocortisone. Benign /non-tumorigenic (I-7/HaCaT) and malignant low metastatic/high metastatic (II-3/RT-3) keratinocytes were treated with ACTH and assessed for determine the levels of cortisol being synthesized. It was found that the malignant keratinocytes secreted higher levels of endogenous hydrocortisone in response to ACTH treatment compared to benign keratinocytes (Kennedy et al., 2015). Overall, this study 
demonstrates the interaction between glucocorticoids and keratinocytes during cancer progression. These findings indicate that epidermal glucocorticoid systems are associated with tumour progression which is of clinical relevance as synthetic corticosteroids are so widely used for potentially malignant conditions.

\section{Alteration of cortisol and related enzymes in malignancy: possible role of the tumour- associated glucocorticoid system}

Alteration of key molecules involved in the glucocorticoid pathway in cancer has been reported in previous literature. For instance, elevated cortisol levels have been found in cancer patients where it is believed it affects cancer prognosis by impairing the cellular and humoral immune response and by promoting tumour metastasis (Bernabé et al., 2012; Mazzoccoli et al., 2003; Rasmuson et al., 2001).

$11 \beta$-Hydroxysteroid dehydrogenase $(11 \beta-\mathrm{HSD})$ is the main enzyme that regulates the endogenous activity of GCs and is expressed in two isoforms, type 1 and type 2. These two

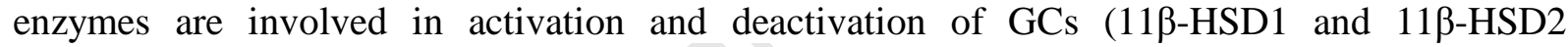
respectively), thus controlling cell proliferation. Expression of $11 \beta-\mathrm{HSD} 1$ generally results in decrease in cell proliferation, whereas expression of $11 \beta-\mathrm{HSD} 2$ is involved in increase in cell proliferation. Studies have illustrated that expression of these enzymes is altered in tumours and may create a microenvironment favourable for tumour growth. For instance, an earlier study on murine and human epidermal cells observed the involvement of 11ß-HSD1 in the natural skin ageing process (Tiganescu et al., 2013). It was found that 11ß-HSD1 expression increases in ageing skin, resulting in local GC excess and adverse effects such as: altered skin integrity, thinning and impaired wound healing. This is due to the changes in the extracellular matrix (ECM) including: collagen atrophy, collagen disorganisation, shredded appearance of collagen 
structure and large inter-fibril spaces. This disordered ECM microenvironment is vital for tumour metastasis. Hence the study suggested that the local increase in 11 $\beta$-HSD1 in ageing skin may increase the risk of skin cancer.

The GC receptor (GR) also plays a key role in the glucocorticoid pathway. It is a member of the nuclear hormone receptor family normally located within the cytoplasm of cells. Upon binding with cortisol it migrates to the nucleus and functions as a transcription activator or repressor that affects gene regulation to ultimately cause decreased cell proliferation (Schlossmacher et al., 2011; Slominski et al., 2014). Mutations in GR structure, aberrant processing of GR pre-mRNA and impaired functionality have been implicated in cancer progression.

Table I lists studies that have demonstrated dysregulation of cortisol, 11ß-HSD enzymes and glucocorticoid receptor in different types of cancers.

\section{Use of corticosteroids in malignancy and premalignant conditions}

GCs have a wide array of uses and effects in premalignant and malignant conditions. As strong anti-inflammatory agents, they have the ability to regulate cell fate by inducing expression of anti-apoptotic genes while suppressing apoptotic factors (Oakley and Cidlowski, 2011; Sung et al., 2009). Additionally, GCs are used as analgesics and antiemetics by patients receiving cancer treatment (Stojadinovic et al., 2007).

There are possible mechanism-based benefits in the use of GCs in pre-malignant conditions. An example of a potentially malignant condition that has potential for transformation is oral lichen planus. Progression to oral SCC can occur in up to 5.8\% of cases (Kaplan et al., 2012; Kesić et al., 2009). Lichen planus is an autoimmune condition characterized by chronic inflammation (Ismail et al., 2007). It is postulated that chronic inflammation is a factor that may lead to the 
development of malignancy such as oral SCC. The powerful anti-inflammatory effects of GCs may therefore be a protective factor in this situation, and they are currently first-line treatment for this condition (Lodi et al., 2012; Scully et al., 2000; Usatine and Tinitigan, 2011). Nevertheless, the recent finding that GCs may bear cancer-promoting effects warrants further consideration in this area.

GCs are used as a monotherapy or in combination with other treatments to manage and treat many different forms of malignancy. GC monotherapy has been shown to have positive treatment outcomes in patients with breast and prostate cancer via proposed mechanisms of adrenocortical inhibition and adrenal androgen suppression respectively (Keith, 2008). In a systematic review investigating the combination therapy of chemotherapy +/- GCs, evidence supported such added treatment outcomes as decreased leukopenia, decreased thrombocytopenia and an improved tolerance for increased chemotherapy dose in the group that received GCs as an adjunct to their chemotherapy compared to the group only receiving chemotherapy (Keith, 2008). Corticosteroids are also prescribed for the treatment of hypercalcaemia associated with malignancy. Renal tubular resistance to endogenous calcitonin during treatment for hypercalcaemia in malignancy can be overcome by the addition of corticosteroids to the treatment (Hosking et al., 1990). Despite their benefits in cancer treatment, GCs have also paradoxically been implicated in cancer progression (Nakane et al., 1990; Sidler et al., 2011; Zhang et al., 2006). The postulated benefits of corticosteroids in preventing malignancy should therefore be balanced against the possible carcinogenic effects of immunosuppression warranting further research in this area.

In a study of the primary adult brain tumour, glioblastoma, the use of GCs as part of the standard treatment protocol was examined. The standard treatment protocol for primary adult tumours 
included maximum surgical resection, radiation therapy and chemotherapy with about $99 \%$ of the patients also receiving perioperative corticosteroids with some patients receiving continued doses throughout the course of care (Seyfried et al., 2010). High dose GCs are generally prescribed for their anti-inflammatory mechanism to help combat radiation therapy associated brain swelling and tumour oedema (a conventional use and effect). However, GCs such as Dexamethasone that are regularly prescribed have been shown to considerably increase blood glucose levels. The blood glucose is a fuel for glycolysis-dependant tumours and also facilitates production of glutamate, a neurotransmitter linked with causing excitotoxic damage to neurons (Seyfried et al., 2010). Higher levels of blood glucose have been shown to accelerate brain tumour growth and lower treatment prognosis (Seyfried et al., 2010).

Glucocorticoid-induced resistance has been identified in cells of solid tumours when used with various anticancer drugs and with radiotherapy. Such observations were made in established carcinoma cell lines cultured in vitro, in xenografts on nude mice, and in primary cells that had been isolated from fresh surgical samples of solid tumours (Herr et al., 2003; Sui et al., 2006; Zhang et al., 2006). Tumours analysed were derived from bladder, brain, breast, cervix, colon or rectum, liver, lung, kidney, ovary, pancreas, and prostate. The finding that the tumour-associated glucocorticoid system is active in all these tumours (Cirillo et al., manuscript in preparation) adds a further level of complexity and raises the possibility that a de-regulated GC metabolism may serve as a tumour promoting mechanism in cancer (Figure 1).

Overall, it can be ascertained from the wide array of research on this topic that the effects and uses of GCs in malignant conditions can be both beneficial and detrimental in terms of controlling tumour growth and progression. Conventional uses of GCs have been shown to help treat malignant conditions either alone or in combination with other treatment modalities. Yet the 
literature also supports the adverse effects of GCs in tumour progression and growth which are linked closely to the non-conventional effects of GCs in malignant conditions.

\section{Conclusion}

Based on preliminary data and evidence obtained from this literature review it can be suggested that in contrast to previous thought, increased levels of autocrine, paracrine and exogenous cortisol are important to tumour progression. Hence it is possible that alterations in the expression of enzymes regulating the levels of tumour-derived cortisol take place in cancers. It will be important, therefore, to assess the levels of expression of steroidogenic molecules, steroids and receptors amongst normal and malignant epithelial cells as well as the correlation of the expression levels of steroid-related molecules to the clinical-pathological parameters of cancer.

In addition to shedding light on key patho-physiological mechanisms of SCC, characterization of the tumour-associated GC systems will have salient diagnostic, preventive and therapeutic clinical implications. Changes in the expression levels of components of the epithelial GC pathway may aid in the selection of novel markers of cancer progression. Identification of the presence of alterations in the steroid pathway in malignant epithelial cells would open new avenues in the management of inflammatory pre-malignant conditions such as lichen planus and provide basis for a mechanism-based approach to cancer treatment.

\section{References:}


Bernabé DG, Tamae AC, Biasoli ÉR, Oliveira SH. 2011. Stress hormones increase cell proliferation and regulates interleukin-6 secretion in human oral squamous cell carcinoma cells. Brain, behavior, and immunity 25(3):574-583.

Bernabé DG, Tamae AC, Miyahara GI, Sundefeld MLM, Oliveira SP, Biasoli ÉR. 2012. Increased plasma and salivary cortisol levels in patients with oral cancer and their association with clinical stage. Journal of clinical pathology 65(10):934-939.

Bland R, Worker C, Noble B, Eyre L, Bujalska I, Sheppard M, Stewart P, Hewison M. 1999. Characterization of 11beta-hydroxysteroid dehydrogenase activity and corticosteroid receptor expression in human osteosarcoma cell lines. Journal of Endocrinology 161(3):455-464.

Budunova IV, Carbajal S, Kang Hi, Viaje A, Slaga TJ. 1997. Altered glucocorticoid receptor expression and function during mouse skin carcinogenesis. Molecular carcinogenesis 18(3):177-185.

Cirillo N, Hassona Y, Pignatelli M, Gasparoto T, Morgan D, Prime S. 2012. Characterization of a novel oral glucocorticoid system and its possible role in disease. Journal of dental research 91(1):97-103.

Cirillo N, Prime SS. 2011. Keratinocytes synthesize and activate cortisol. Journal of cellular biochemistry 112(6):1499-1505.

Deguchi M, Isobe Y, Matsukawa S, Yamaguchi A, Nakagawara G. 1998. Usefulness of metyrapone treatment to suppress cancer metastasis facilitated by surgical stress. Surgery 123(4):440-449. 
Duffy SA, Taylor JM, Terrell JE, Islam M, Li Y, Fowler KE, Wolf GT, Teknos TN. 2008. Interleukin-6 predicts recurrence and survival among head and neck cancer patients. Cancer 113(4):750-757.

Feng X, Reini SA, Richards E, Wood CE, Keller-Wood M. 2013. Cortisol stimulates proliferation and apoptosis in the late gestation fetal heart: differential effects of mineralocorticoid and glucocorticoid receptors. American Journal of PhysiologyRegulatory, Integrative and Comparative Physiology 305(4):R343-R350.

Feng Z, Liu L, Zhang C, Zheng T, Wang J, Lin M, Zhao Y, Wang X, Levine AJ, Hu W. 2012. Chronic restraint stress attenuates p53 function and promotes tumorigenesis. Proceedings of the National Academy of Sciences 109(18):7013-7018.

Guendisch S, Boeckeler E, Behrends U, Amtmann E, Ehrhardt H, Jeremias I. 2012. Glucocorticoids augment survival and proliferation of tumor cells. Anticancer research 32(10):4251-4261.

Heikkilä K, Ebrahim S, Lawlor DA. 2008. Systematic review of the association between circulating interleukin-6 (IL-6) and cancer. European journal of cancer 44(7):937-945.

Herr I, Ucur E, Herzer K, et al. 2003. Glucocorticoid co-treatment induces apoptosis resistance toward cancer therapy in carcinomas. Cancer Research 63: 3112-20.

Herr I, Pfitzenmaier J. 2006. Glucocorticoid use in prostate cancer and other solid tumours: implications for effectiveness of cytotoxic treatment and metastases. Lancet Oncol. $7(5): 425-30$.

Hosking D, Stone M, Foote J. 1990. Potentiation of calcitonin by corticosteroids during the treatment of the hypercalcaemia of malignancy. European journal of clinical pharmacology 38(1):37-41. 
Ismail SB, Kumar SK, Zain RB. 2007. Oral lichen planus and lichenoid reactions: etiopathogenesis, diagnosis, management and malignant transformation. Journal of oral science 49(2):89-106.

Itoi S, Terao M, Murota H, Katayama I. 2013. 11ß-Hydroxysteroid dehydrogenase 1 contributes to the pro-inflammatory response of keratinocytes. Biochem Biophys Res Commun. 440(2):265-70.

Jobe NP, Rösel D, Dvořánková B, Kodet O, Lacina L, Mateu R, Smetana K, Brábek J.

Simultaneous blocking of IL-6 and IL-8 is sufficient to fully inhibit CAF-induced human melanoma cell invasiveness. Histochem Cell Biol. 2016 Apr 21

Kaplan I, Ventura-Sharabi Y, Gal G, Calderon S, Anavi Y. 2012. The dynamics of oral lichen planus: a retrospective clinicopathological study. Head and neck pathology 6(2):178-183.

Kay P, Schlossmacher G, Matthews L, Sommer P, Singh D, White A, Ray D. 2011. Loss of glucocorticoid receptor expression by DNA methylation prevents glucocorticoid induced apoptosis in human small cell lung cancer cells. PloS one 6(10):e24839.

Keith BD. 2008. Systematic review of the clinical effect of glucocorticoids on nonhematologic malignancy. BMC cancer 8(1):1.

Kennedy D, Pignatelli M, Hassona Y. 2015. The Role of the Glucocorticoid System in Anchorage-independence during Progression of Squamous Cell Carcinoma. American Journal of Oral Medicine 1(1):8-19.

Kenouch S, Lombes M, Delahaye F, Eugene E, Bonvalet J-P, Farman N. 1994. Human skin as target for aldosterone: coexpression of mineralocorticoid receptors and 11 betahydroxysteroid dehydrogenase. The Journal of Clinical Endocrinology \& Metabolism 79(5):1334-1341. 
Kesić L, Obradović R, Mihailović D, Radičević G, Stanković S, Todorović K. 2009. Incidence and treatment outcome of oral lichen planus in southeast Serbia in a 10-year period (1997-2007). Vojnosanitetski pregled 66(6):434-439.

Lanza A, Stellavato A, Heulfe I, Landi C, Gombos F, Cirillo N. 2009. Serum of patients with oral pemphigus vulgaris impairs keratinocyte wound repair in vitro: a time-lapse study on the efficacy of methylprednisolone and pyridostigmine bromide. Oral diseases 15(7):478483.

Li J, Johnson TA, Hanson LA, Beer DG. 1996. Loss of glucocorticoid-dependent growth inhibition in transformed mouse lung cells. Molecular carcinogenesis 16(4):213-220.

Lodi G, Carrozzo M, Furness S, Thongprasom K. 2012. Interventions for treating oral lichen planus: a systematic review. British Journal of Dermatology 166(5):938-947.

Lu L, Zhao G, Ouellet J, Fan Z, Labrie F, Pelletier G. 2011. Expression of 11 $\beta$-hydroxysteroid dehydrogenase type 1 in breast cancer and adjacent non-malignant tissue. An immunocytochemical study. Pathology \& Oncology Research 17(3):627-632.

Mazzoccoli G, Carughi S, De Cata A, La Viola M, Giuliani A, Tarquini R, Perfetto F. 2003. Neuroendocrine alterations in lung cancer patients. Neuroendocrinology Letters 24(1/2):77-82.

Nagata M, Fujita H, Ida H, Hoshina H, Inoue T, Seki Y, Ohnishi M, Ohyama T, Shingaki S, Kaji M. 2003. Identification of potential biomarkers of lymph node metastasis in oral squamous cell carcinoma by cDNA microarray analysis. International journal of cancer 106(5):683-689. 
Nakane T, Szentendrei T, Stern L, Virmani M, Seely J, Kunos G. 1990. Effects of IL-1 and cortisol on beta-adrenergic receptors, cell proliferation, and differentiation in cultured human A549 lung tumor cells. The Journal of Immunology 145(1):260-266.

Newton R. 2000. Molecular mechanisms of glucocorticoid action: what is important? Thorax 55(7):603-613.

Oakley RH, Cidlowski JA. 2011. Cellular processing of the glucocorticoid receptor gene and protein: new mechanisms for generating tissue-specific actions of glucocorticoids. Journal of biological chemistry 286(5):3177-3184.

Olnes MJ, Kotliarov Y, Biancotto A, Cheung F, Chen J, Shi R, Zhou H, Wang E, Tsang JS, Nussenblatt R; CHI Consortium. 2016. Effects of Systemically Administered Hydrocortisone on the Human Immunome. Sci Rep 6:23002.

Parks LL, Turney MK, Detera-Wadleigh S, Kovacs WJ. 1998a. An ACTH-producing small cell lung cancer expresses aberrant glucocorticoid receptor transcripts from a normal gene. Molecular and cellular endocrinology 142(1):175-181.

Parks LL, Turney MK, Gaitan D, Kovacs WJ. 1998b. Expression of 11ß-hydroxysteroid dehydrogenase type 2 in an ACTH-producing small cell lung cancer. The Journal of steroid biochemistry and molecular biology 67(4):341-346.

Rabbitt E, Gittoes N, Stewart P, Hewison M. 2003. 11ß-hydroxysteroid dehydrogenases, cell proliferation and malignancy. The Journal of steroid biochemistry and molecular biology $85(2): 415-421$.

Rasmuson T, Ljungberg B, Grankvist K, Jacobsen J, Olsson T. 2001. Increased serum cortisol levels are associated with high tumour grade in patients with renal cell carcinoma. Acta Oncologica 40(1):83-87. 
Ray DW, Davis JR, White A, Clark AJ. 1996. Glucocorticoid receptor structure and function in glucocorticoid-resistant small cell lung carcinoma cells. Cancer research 56(14):32763280.

Ren R, Oakley RH, Cruz-Topete D, Cidlowski JA. 2012. Dual role for glucocorticoids in cardiomyocyte hypertrophy and apoptosis. Endocrinology 153(11):5346-5360.

Romero LM, Raley-Susman KM, Redish DM, Brooke SM, Horner HC, Sapolsky RM. 1992. Possible mechanism by which stress accelerates growth of virally derived tumors. Proceedings of the National Academy of Sciences 89(22):11084-11087.

Sanchis A, Alba L, Latorre V, Sevilla LM, Pérez P. 2012. Keratinocyte-targeted overexpression of the glucocorticoid receptor delays cutaneous wound healing. PloS one 7(1):e29701.

Schlossmacher G, Stevens A, White A. 2011. Glucocorticoid receptor-mediated apoptosis: mechanisms of resistance in cancer cells. Journal of Endocrinology 211(1):17-25.

Scully C, Eisen D, Carrozzo M. 2000. Management of oral lichen planus. American journal of clinical dermatology 1(5):287-306.

Sephton SE, Lush E, Dedert EA, Floyd AR, Rebholz WN, Dhabhar FS, Spiegel D, Salmon P. 2013. Diurnal cortisol rhythm as a predictor of lung cancer survival. Brain, behavior, and immunity 30:S163-S170.

Sephton SE, Sapolsky RM, Kraemer HC, Spiegel D. 2000. Diurnal cortisol rhythm as a predictor of breast cancer survival. Journal of the National Cancer Institute 92(12):994-1000.

Seyfried TN, Shelton LM, Mukherjee P. 2010. Does the existing standard of care increase glioblastoma energy metabolism? The lancet oncology 11(9):811-813. 
Sidler D, Renzulli P, Schnoz C, Berger B, Schneider-Jakob S, Flück C, Inderbitzin D, Corazza N, Candinas D, Brunner T. 2011. Colon cancer cells produce immunoregulatory glucocorticoids. Oncogene 30(21):2411-2419.

Slominski AT, Manna PR, Tuckey RC. 2014. Cutaneous glucocorticosteroidogenesis: securing local homeostasis and the skin integrity. Experimental dermatology 23(6):369-374.

Spiegelman VS, Budunova IV, Carbajal S, Slaga TJ. 1997. Resistance of transformed mouse keratinocytes to growth inhibition by glucocorticoids. Molecular carcinogenesis 20(1):99-107.

Stojadinovic O, Lee B, Vouthounis C, Vukelic S, Pastar I, Blumenberg M, Brem H, TomicCanic M. 2007. Novel Genomic Effects of Glucocorticoids in Epidermal Keratinocytes INHIBITION OF APOPTOSIS, INTERFERON- $\gamma$ PATHWAY, AND WOUND HEALING ALONG WITH PROMOTION OF TERMINAL DIFFERENTIATION. Journal of Biological Chemistry 282(6):4021-4034.

Sui M, Chen F, Chen Z, Fan W. 2006. Glucocorticoids interfere with therapeutic efficacy of paclitaxel against human breast and ovarian xenograft tumors. Int J Cancer. 119(3):712-7

Sung J, Song Y-M, Lawlor DA, Smith GD, Ebrahim S. 2009. Height and site-specific cancer risk: a cohort study of a Korean adult population. American journal of epidemiology 170(1):53-64.

Temkin S, Nacharaju VL, Hellman M, Lee Y-C, Abulafia O. 2006. Type 2 11ß-hydroxysteroid dehydrogenase activity in human ovarian cancer. Steroids 71(11):1019-1023.

Terao M, Itoi S, Murota H, Katayama I. 2013. Expression profiles of cortisol-inactivating enzyme, 11ß-hydroxysteroid dehydrogenase-2, in human epidermal tumors and its role in keratinocyte proliferation. Experimental dermatology 22(2):98-101. 
Tiganescu A, Tahrani AA, Morgan SA, Otranto M, Desmoulière A, Abrahams L, Hassan-Smith Z, Walker EA, Rabbitt EH, Cooper MS. 2013. 11ß-Hydroxysteroid dehydrogenase blockade prevents age-induced skin structure and function defects. The Journal of clinical investigation 123(7):3051-3060.

Usatine RP, Tinitigan M. 2011. Diagnosis and treatment of lichen planus. American family physician 84(1).

Wadsworth SJ, Nijmeh HS, Hall IP. 2006. Glucocorticoids increase repair potential in a novel in vitro human airway epithelial wounding model. Journal of clinical immunology 26(4):376-387.

Xing K, Gu B, Zhang P, Wu X. 2015. Dexamethasone enhances programmed cell death 1 (PD-1) expression during T cell activation: an insight into the optimum application of glucocorticoids in anti-cancer therapy. BMC Immunol. Jun 16:39.

Yuan HJ, Han X, He N, Wang GL, Gong S, Lin J, Gao M, Tan JH. 2016. Glucocorticoids impair oocyte developmental potential by triggering apoptosis of ovarian cells via activating the Fas system. Sci Rep. 6:24036

Žbánková Š, Bryndová J, Kment M, Pácha J. 2004. Expression of 11ß-hydroxysteroid dehydrogenase types 1 and 2 in colorectal cancer. Cancer letters 210(1):95-100.

Zhang C, Beckermann B, Kallifatidis G, Liu Z, Rittgen W, Edler L, Büchler P, Debatin K-M, Büchler MW, Friess H. 2006. Corticosteroids induce chemotherapy resistance in the majority of tumour cells from bone, brain, breast, cervix, melanoma and neuroblastoma. International journal of oncology 29(5):1295-1301.

Zhang C, Mattern J, Haferkamp A, et al. 2006. Corticosteroid-induced chemotherapy resistance in urological cancers. Cancer Biol Ther 5: 59-64 
Table I. Dysregulation of serum cortisol, 11ß-HSDs and glucocorticoid receptor in different types of cancers.

\begin{tabular}{|c|c|c|c|}
\hline Study & $\begin{array}{l}\text { Type of } \\
\text { Cancer }\end{array}$ & $\begin{array}{l}\text { Dysregulate } \\
\text { d Molecule }\end{array}$ & Specific Findings \\
\hline $\begin{array}{l}\text { (Bernabé et } \\
\text { al., 2012) }\end{array}$ & $\begin{array}{l}\text { Oral squamous } \\
\text { cell carcinoma } \\
\text { (SCC) }\end{array}$ & Cortisol & $\begin{array}{l}\text { Elevated plasma and salivary } \\
\text { cortisol levels in SCC and also } \\
\text { higher levels in advanced stage } \\
\text { compared to initial stage. }\end{array}$ \\
\hline $\begin{array}{l}\text { (Rasmuson } \\
\text { et al., 2001) }\end{array}$ & $\begin{array}{l}\text { Renal cell } \\
\text { carcinoma } \\
(\mathrm{RCC})\end{array}$ & Cortisol & $\begin{array}{l}\text { Serum cortisol levels higher in RCC } \\
\text { and positively correlated with } \\
\text { tumour diameter and grade. Elevated } \\
\text { cortisol levels also had worse } \\
\text { prognosis. }\end{array}$ \\
\hline $\begin{array}{l}\text { (Sephton et } \\
\text { al., 2000) }\end{array}$ & $\begin{array}{l}\text { Metastatic } \\
\text { breast cancer }\end{array}$ & Cortisol & $\begin{array}{l}\text { Flat diurnal salivary cortisol } \\
\text { circadian rhythm where elevated } \\
\text { cortisol levels associated with early } \\
\text { mortality. }\end{array}$ \\
\hline $\begin{array}{l}\text { (Sephton et } \\
\text { al., 2013) }\end{array}$ & Lung cancer & Cortisol & $\begin{array}{l}\text { Flattening of the diurnal cortisol } \\
\text { rhythm associated with early death. }\end{array}$ \\
\hline $\begin{array}{l}\text { (Terao et al., } \\
\text { 2013) }\end{array}$ & $\begin{array}{l}\text { Skin SCC, } \\
\text { basal cell } \\
\text { carcinoma } \\
\text { (BCC) and } \\
\text { seborrheic } \\
\text { keratosis (SK) }\end{array}$ & $\begin{array}{l}11 \beta-H S D 1 \\
\text { and } 11 \beta- \\
\text { HSD2 } \\
\text { enzyme }\end{array}$ & $\begin{array}{l}\text { Reduction in } 11 \beta \text {-HSD1 expression } \\
\text { with increased keratinocyte } \\
\text { proliferation. } 11 \beta \text {-HSD2 expression } \\
\text { increased in basal cell proliferating } \\
\text { conditions such as BCC and SK. }\end{array}$ \\
\hline $\begin{array}{l}\text { (Parks et al., } \\
\text { 1998b) }\end{array}$ & $\begin{array}{l}\text { DMS-79 cells } \\
\text { (cell line } \\
\text { derived from } \\
\text { an ACTH- } \\
\text { producing } \\
\text { small cell lung } \\
\text { cancer). }\end{array}$ & $\begin{array}{l}11 \beta-H S D 2 \\
\text { enzyme }\end{array}$ & $\begin{array}{l}11 \beta \text {-HSD } 2 \text { normally not found in } \\
\text { healthy lung tissue, was expressed in } \\
\text { cancerous lung tissue. }\end{array}$ \\
\hline $\begin{array}{l}\text { (Temkin et } \\
\text { al., 2006) }\end{array}$ & $\begin{array}{l}\text { Ovarian } \\
\text { epithelial } \\
\text { cancer }\end{array}$ & $\begin{array}{l}\text { 11ß-HSD2 } \\
\text { enzyme }\end{array}$ & $\begin{array}{l}11 \beta \text {-HSD } 2 \text { enzyme not found in } \\
\text { normal post-menopausal ovarian } \\
\text { tissue was increased in cancer cells. }\end{array}$ \\
\hline $\begin{array}{l}\text { (Bland et al., } \\
\text { 1999) }\end{array}$ & Osteosarcoma & $\begin{array}{l}11 \beta \text {-HSD2 } \\
\text { enzyme }\end{array}$ & $\begin{array}{l}\text { Overexpression of } 11 \beta-\mathrm{HSD} 2 \\
\text { enzyme in cancer, compared with } \\
\text { nradnminant evnreccion of } 11 R_{-}\end{array}$ \\
\hline
\end{tabular}




\begin{tabular}{|c|c|c|c|}
\hline & & & $\begin{array}{l}\text { HSD1 enzyme in normal human } \\
\text { osteoblast cells. }\end{array}$ \\
\hline $\begin{array}{l}\text { (Žbánková et } \\
\text { al., 2004) }\end{array}$ & $\begin{array}{l}\text { Colorectal } \\
\text { cancer }\end{array}$ & $\begin{array}{l}11 \beta-H S D 2 \\
\text { and } 11 \beta- \\
\text { HSD1 } \\
\text { enzyme }\end{array}$ & $\begin{array}{l}\text { Decrease in the abundance of } 11 \beta \text { - } \\
\text { HSD } 2 \text { mRNA and enzyme activity } \\
\text { in cancer tissue. Also demonstrated } \\
\text { increase in } 11 \beta \text {-HSD } 1 \text { in some } \\
\text { samples. }\end{array}$ \\
\hline $\begin{array}{l}\text { (Cirillo et } \\
\text { al., 2012) }\end{array}$ & $\begin{array}{l}\text { Oral squamous } \\
\text { cell carcinoma } \\
(\text { SCC })\end{array}$ & $\begin{array}{l}11 \beta \text {-HSD2 } \\
\text { enzyme }\end{array}$ & $\begin{array}{l}\text { Decrease in } 11 \beta-H S D 2 \text { expression in } \\
\text { cancer. }\end{array}$ \\
\hline $\begin{array}{l}\text { (Lu et al., } \\
\text { 2011) }\end{array}$ & Breast cancer & $\begin{array}{l}11 \beta \text {-HSD1 } \\
\text { enzyme }\end{array}$ & $\begin{array}{l}\text { Decrease in } 11 \beta \text {-HSD1 expression in } \\
\text { cancer. }\end{array}$ \\
\hline $\begin{array}{l}\text { (Budunova } \\
\text { et al., 1997) }\end{array}$ & $\begin{array}{l}\text { Mouse } \\
\text { epidermal } \\
\text { papillomas and } \\
\text { SCC. }\end{array}$ & $\begin{array}{l}\text { Glucocorticoi } \\
\text { d receptor }\end{array}$ & $\begin{array}{l}\text { In early skin papilloma GR } \\
\text { expression is reduced but in late } \\
\text { papilloma and in SCC, GR levels are } \\
\text { similar or higher than normal. }\end{array}$ \\
\hline $\begin{array}{l}\text { (Spiegelman } \\
\text { et al., 1997) }\end{array}$ & $\begin{array}{l}\text { Mouse } \\
\text { epidermal } \\
\text { papillomas and } \\
\text { SCC. }\end{array}$ & $\begin{array}{l}\text { Glucocorticoi } \\
\text { d receptor }\end{array}$ & $\begin{array}{l}\text { No significant changes in GR gene } \\
\text { structure and expression in cancer } \\
\text { but resistance to glucocorticoid } \\
\text { fluocinolone acetonid more likely } \\
\text { due to alterations in receptor } \\
\text { function. }\end{array}$ \\
\hline $\begin{array}{l}\text { (Waters et } \\
\text { al., 2004) }\end{array}$ & $\begin{array}{l}\text { Small cell lung } \\
\text { carcinoma } \\
\text { (SCLC) }\end{array}$ & $\begin{array}{l}\text { Glucocorticoi } \\
\text { d receptor }\end{array}$ & $\begin{array}{l}\text { Normal expression of GR, however } \\
\text { its functionality altered by subtle } \\
\text { changes in co-factors such as } \\
\text { Nuclear co-repressor which was } \\
\text { overexpressed in cancer. }\end{array}$ \\
\hline $\begin{array}{l}\text { (Ray et al., } \\
1996)\end{array}$ & $\begin{array}{l}\text { Small cell lung } \\
\text { carcinoma } \\
\text { (SCLC) }\end{array}$ & $\begin{array}{l}\text { Glucocorticoi } \\
\text { d receptor }\end{array}$ & $\begin{array}{l}\text { Mutations in GR gene structure lead } \\
\text { to its impaired function. }\end{array}$ \\
\hline $\begin{array}{l}\text { (Parks et al., } \\
\text { 1998a) }\end{array}$ & $\begin{array}{l}\text { Small cell lung } \\
\text { carcinoma } \\
\text { (SCLC) }\end{array}$ & $\begin{array}{l}\text { Glucocorticoi } \\
\text { d receptor }\end{array}$ & $\begin{array}{l}\text { Abnormal splicing of the GR } \\
\text { transcript causes GR resistance to } \\
\text { GC stimulation in cancer cells. }\end{array}$ \\
\hline $\begin{array}{l}\text { (Kay et al., } \\
\text { 2011) }\end{array}$ & $\begin{array}{l}\text { Small cell lung } \\
\text { carcinoma } \\
\text { (SCLC) }\end{array}$ & $\begin{array}{l}\text { Glucocorticoi } \\
\text { d receptor }\end{array}$ & $\begin{array}{l}\text { Increased DNA methylation of } \\
\text { promoter c leads to decreased GR } \\
\text { expression. }\end{array}$ \\
\hline $\begin{array}{l}\text { (Li et al., } \\
\text { 1996) }\end{array}$ & $\begin{array}{l}\text { Transformed } \\
\Delta 5 \text { mnice luns }\end{array}$ & $\begin{array}{l}\text { Glucocorticoi } \\
\text { d receptor }\end{array}$ & $\begin{array}{l}\text { Transformed cells contain functional } \\
\text { SR hut avnrece rim w which }\end{array}$ \\
\hline
\end{tabular}




\begin{tabular}{|l|l|l|l|}
\hline & cells & & antagonises glucocorticoids. \\
\hline
\end{tabular}

\section{Legend to figures}

Figure 1. Schematic representation of cancer-promoting glucocorticoid effects.

Table I. Dysregulation of serum cortisol, 11ß-HSDs and glucocorticoid receptor in different types of cancers.

\begin{tabular}{|l|l|l|l|}
\hline \multicolumn{1}{|c|}{ Study } & \multicolumn{1}{|c|}{$\begin{array}{c}\text { Type of } \\
\text { Cancer }\end{array}$} & $\begin{array}{l}\text { Dysregulate } \\
\text { d Molecule }\end{array}$ & \multicolumn{1}{c|}{ Specific Findings } \\
\hline $\begin{array}{l}\text { (Bernabé et } \\
\text { al., 2012) }\end{array}$ & $\begin{array}{l}\text { Oral squamous } \\
\text { cell carcinoma } \\
\text { (SCC) }\end{array}$ & Cortisol & $\begin{array}{l}\text { Elevated plasma and salivary } \\
\text { cortisol levels in SCC and also } \\
\text { higher levels in advanced stage } \\
\text { compared to initial stage. }\end{array}$ \\
\hline $\begin{array}{l}\text { (Rasmuson } \\
\text { et al., 2001) }\end{array}$ & $\begin{array}{l}\text { Renal cell } \\
\text { carcinoma } \\
\text { (RCC) }\end{array}$ & Cortisol & $\begin{array}{l}\text { Serum cortisol levels higher in RCC } \\
\text { and positively correlated with } \\
\text { tumour diameter and grade. Elevated } \\
\text { cortisol levels also had worse } \\
\text { prognosis. }\end{array}$ \\
\hline r canhton at & Matactatir & Cortisol & Flat diurnal calivaru norticnl \\
\hline
\end{tabular}




\begin{tabular}{|c|c|c|c|}
\hline al., 2000) & breast cancer & & $\begin{array}{l}\text { circadian rhythm where elevated } \\
\text { cortisol levels associated with early } \\
\text { mortality. }\end{array}$ \\
\hline $\begin{array}{l}\text { (Sephton et } \\
\text { al., 2013) }\end{array}$ & Lung cancer & Cortisol & $\begin{array}{l}\text { Flattening of the diurnal cortisol } \\
\text { rhythm associated with early death. }\end{array}$ \\
\hline $\begin{array}{l}\text { (Terao et al., } \\
\text { 2013) }\end{array}$ & $\begin{array}{l}\text { Skin SCC, } \\
\text { basal cell } \\
\text { carcinoma } \\
\text { (BCC) and } \\
\text { seborrheic } \\
\text { keratosis (SK) }\end{array}$ & $\begin{array}{l}11 \beta-H S D 1 \\
\text { and } 11 \beta- \\
\text { HSD2 } \\
\text { enzyme }\end{array}$ & $\begin{array}{l}\text { Reduction in } 11 \beta \text {-HSD1 expression } \\
\text { with increased keratinocyte } \\
\text { proliferation. } 11 \beta \text {-HSD2 expression } \\
\text { increased in basal cell proliferating } \\
\text { conditions such as BCC and SK. }\end{array}$ \\
\hline $\begin{array}{l}\text { (Parks et al., } \\
\text { 1998b) }\end{array}$ & $\begin{array}{l}\text { DMS-79 cells } \\
\text { (cell line } \\
\text { derived from } \\
\text { an ACTH- } \\
\text { producing } \\
\text { small cell lung } \\
\text { cancer). }\end{array}$ & $\begin{array}{l}11 \beta \text {-HSD2 } \\
\text { enzyme }\end{array}$ & $\begin{array}{l}11 \beta-H S D 2 \text { normally not found in } \\
\text { healthy lung tissue, was expressed in } \\
\text { cancerous lung tissue. }\end{array}$ \\
\hline $\begin{array}{l}\text { (Temkin et } \\
\text { al., 2006) }\end{array}$ & $\begin{array}{l}\text { Ovarian } \\
\text { epithelial } \\
\text { cancer }\end{array}$ & $\begin{array}{l}11 \beta \text {-HSD2 } \\
\text { enzyme }\end{array}$ & $\begin{array}{l}11 \beta-H S D 2 \text { enzyme not found in } \\
\text { normal post-menopausal ovarian } \\
\text { tissue was increased in cancer cells. }\end{array}$ \\
\hline $\begin{array}{l}\text { (Bland et al., } \\
\text { 1999) }\end{array}$ & Osteosarcoma & $\begin{array}{l}11 \beta \text {-HSD2 } \\
\text { enzyme }\end{array}$ & $\begin{array}{l}\text { Overexpression of } 11 \beta \text {-HSD2 } \\
\text { enzyme in cancer, compared with } \\
\text { predominant expression of } 11 \beta- \\
\text { HSD1 enzyme in normal human } \\
\text { osteoblast cells. }\end{array}$ \\
\hline $\begin{array}{l}\text { (Žbánková et } \\
\text { al., 2004) }\end{array}$ & $\begin{array}{l}\text { Colorectal } \\
\text { cancer }\end{array}$ & $\begin{array}{l}11 \beta-H S D 2 \\
\text { and } 11 \beta- \\
\text { HSD1 } \\
\text { enzyme }\end{array}$ & $\begin{array}{l}\text { Decrease in the abundance of } 11 \beta \text { - } \\
\text { HSD } 2 \text { mRNA and enzyme activity } \\
\text { in cancer tissue. Also demonstrated } \\
\text { increase in } 11 \beta \text {-HSD } 1 \text { in some } \\
\text { samples. }\end{array}$ \\
\hline $\begin{array}{l}\text { (Cirillo et } \\
\text { al., 2012) }\end{array}$ & $\begin{array}{l}\text { Oral squamous } \\
\text { cell carcinoma } \\
\text { (SCC) }\end{array}$ & $\begin{array}{l}11 \beta \text {-HSD2 } \\
\text { enzyme }\end{array}$ & $\begin{array}{l}\text { Decrease in } 11 \beta \text {-HSD } 2 \text { expression in } \\
\text { cancer. }\end{array}$ \\
\hline $\begin{array}{l}\text { (Lu et al., } \\
\text { 2011) }\end{array}$ & Breast cancer & $\begin{array}{l}11 \beta \text {-HSD1 } \\
\text { enzyme }\end{array}$ & $\begin{array}{l}\text { Decrease in } 11 \beta \text {-HSD1 expression in } \\
\text { cancer. }\end{array}$ \\
\hline $\begin{array}{l}\text { (Budunova } \\
\text { et al., 1997) }\end{array}$ & $\begin{array}{l}\text { Mouse } \\
\text { anidermal }\end{array}$ & $\begin{array}{l}\text { Glucocorticoi } \\
\text { d receptor }\end{array}$ & $\begin{array}{l}\text { In early skin papilloma GR } \\
\text { evnraccion is raduced hut in late }\end{array}$ \\
\hline
\end{tabular}




\begin{tabular}{|l|l|l|l|}
\hline & $\begin{array}{l}\text { papillomas and } \\
\text { SCC. }\end{array}$ & $\begin{array}{l}\text { papilloma and in SCC, GR levels are } \\
\text { similar or higher than normal. }\end{array}$ \\
\hline $\begin{array}{l}\text { (Spiegelman } \\
\text { et al., 1997) }\end{array}$ & $\begin{array}{l}\text { Mouse } \\
\text { epidermal } \\
\text { papillomas and } \\
\text { SCC. }\end{array}$ & $\begin{array}{l}\text { Glucocorticoi } \\
\text { d receptor }\end{array}$ & $\begin{array}{l}\text { No significant changes in GR gene } \\
\text { structure and expression in cancer } \\
\text { but resistance to glucocorticoid } \\
\text { fluocinolone acetonid more likely } \\
\text { due to alterations in receptor } \\
\text { function. }\end{array}$ \\
\hline $\begin{array}{l}\text { (Waters et } \\
\text { al., 2004) }\end{array}$ & $\begin{array}{l}\text { Small cell lung } \\
\text { carcinoma } \\
\text { (SCLC) }\end{array}$ & $\begin{array}{l}\text { Glucocorticoi } \\
\text { d receptor }\end{array}$ & $\begin{array}{l}\text { Normal expression of GR, however } \\
\text { its functionality altered by subtle } \\
\text { changes in co-factors such as } \\
\text { Nuclear co-repressor which was } \\
\text { overexpressed in cancer. }\end{array}$ \\
\hline $\begin{array}{l}\text { (Ray et al., } \\
\text { 1996) }\end{array}$ & $\begin{array}{l}\text { Small cell lung } \\
\text { carcinoma } \\
\text { (SCLC) }\end{array}$ & $\begin{array}{l}\text { Glucocorticoi } \\
\text { d receptor }\end{array}$ & $\begin{array}{l}\text { Mutations in GR gene structure lead } \\
\text { to its impaired function. }\end{array}$ \\
\hline $\begin{array}{l}\text { (Parks et al., } \\
\text { 1998a) }\end{array}$ & $\begin{array}{l}\text { Small cell lung } \\
\text { carcinoma } \\
\text { (SCLC) }\end{array}$ & $\begin{array}{l}\text { Glucocorticoi } \\
\text { d receptor }\end{array}$ & $\begin{array}{l}\text { Abnormal splicing of the GR } \\
\text { transcript causes GR resistance to } \\
\text { GC stimulation in cancer cells. }\end{array}$ \\
\hline $\begin{array}{l}\text { (Kay et al., } \\
\text { 2011) } \\
\text { carcinoma al cell lung } \\
\text { (SCLC) }\end{array}$ & $\begin{array}{l}\text { Transformed } \\
\text { A5 mouse lung } \\
\text { cells }\end{array}$ & $\begin{array}{l}\text { Glucococorticoi } \\
\text { d receptor }\end{array}$ & $\begin{array}{l}\text { Increased DNA methylation of } \\
\text { promoter c leads to decreased GR } \\
\text { expression. }\end{array}$ \\
\hline $\begin{array}{l}\text { Transformed cells contain functional } \\
\text { antagonises glucocorticoids. }\end{array}$ \\
\hline
\end{tabular}




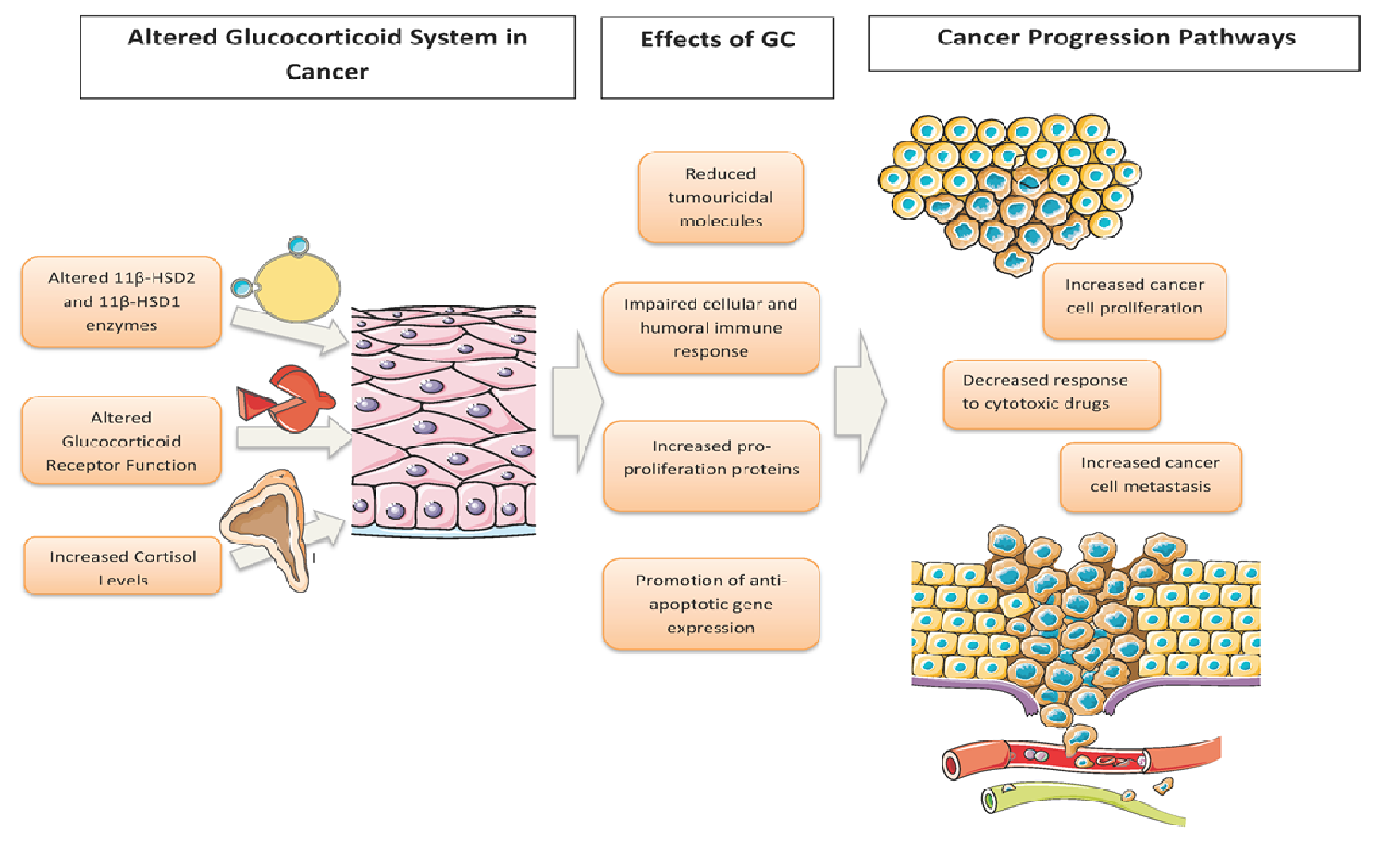

Figure_1 (5) . 


\section{University Library}

\section{- M M N E R VA A gateway to Melbourne's research publications}

Minerva Access is the Institutional Repository of The University of Melbourne

\section{Author/s:}

Azher, S;Azami, O;Amato, C;McCullough, M;Celentano, A;Cirillo, N

Title:

The Non-Conventional Effects of Glucocorticoids in Cancer

\section{Date:}

2016-11-01

Citation:

Azher, S., Azami, O., Amato, C., McCullough, M., Celentano, A. \& Cirillo, N. (2016). The NonConventional Effects of Glucocorticoids in Cancer. JOURNAL OF CELLULAR PHYSIOLOGY, 231 (11), pp.2368-2373. https://doi.org/10.1002/jcp.25408.

Persistent Link:

http://hdl.handle.net/11343/291290 